\title{
Changes in Higher Fatty Acids and Related Biochemical Characteristics of Flue-cured Tobacco during Aging*
}

\author{
by \\ Zhu Daheng ${ }^{1}$, Han Jinfeng ${ }^{2}$, Guan Chunyun ${ }^{3}$ and Chen Rui ${ }^{4}$ \\ ${ }^{1}$ Zhengzhou Tobacco Research Institute of China National Tobacco Company, Zhengzhou, China \\ ${ }^{2}$ Henan Agricultural University, Zhengzhou, China \\ ${ }^{3}$ Hunan Agricultural University, Changsha, China \\ ${ }^{4}$ Beijing Tobacco Supply \& Sale Company, Beijing, China
}

\section{SUMMARY}

The purpose of this study was to investigate the changes in higher fatty acids and related biochemical characteristics of flue-cured tobacco during the process of aging. The concentration of total lipids in flue-cured tobacco decreased gradually during natural aging, but the concentration of individual principal higher fatty acids in fluecured tobacco changed much differently during aging. Myristic acid $\left(\mathrm{C}_{14}: 0\right)$ increased constantly during the whole aging process. Stearic acid $\left(\mathrm{C}_{18}: 0\right)$ and oleic acid $\left(\mathrm{C}_{18}: 1\right)$ increased at the initial stages of aging and reached maximum contents after one year of aging, but decreased thereafter. Palmitic acid $\left(\mathrm{C}_{16}: 0\right)$, linoleic acid $\left(\mathrm{C}_{18}: 2\right)$, and linolenic acid $\left(\mathrm{C}_{18}: 3\right)$ decreased constantly throughout aging, especially the linolenic acid content which decreased drastically. Furthermore, the ratio of unsaturated fatty acids $\left(\mathrm{C}_{18}: 1 ; \mathrm{C}_{18}: 2 ; \mathrm{C}_{18}: 3\right)$ and saturated fatty acids $\left(\mathrm{C}_{14}: 0 ; \mathrm{C}_{16}: 0 ; \mathrm{C}_{18}: 0\right)$ decreased continuously during aging, from 1.00 at the initial stage to 0.43 at the end of aging, when it seemed to be stabilized. The maximum rate of decrease of the ratio was between 12 to 18 mo during aging. The activity of lipoxygenase (LOX) and peroxidation value (POV) initially increased and reached their highest levels after 6 mo of aging, but steadily decreased thereafter. The acid value (AV) and malondialdehyde (MDA) content increased during the first 12 mo of aging, then decreased rapidly after 12 and 18 mo, respectively. [Beitr. Tabakforsch. Int. 19 (2001) 315-19]

\section{ZUSAMMENFASSUNG}

Es wurden die Veränderungen der höheren Fettsäuren und die damit verbundenen biochemischen Eigenschaften bei der Alterung von flue-cured Tabak untersucht. Die Konzentration der Gesamtlipide in flue-cured Tabaken nahm während des natürlichen Aging-Prozesses allmählich ab, während sich die Konzentration bestimmter wichtiger höherer Fettsäuren in flue-cured Tabak während der Alterung in sehr unterschiedlichem Maße änderte. Myristinsäure $\left(\mathrm{C}_{14}: 0\right)$ nahm während des Alterungsprozesses kontinuierlich zu. Stearinsäure $\left(\mathrm{C}_{18}: 0\right)$ und Ölsäure $\left(\mathrm{C}_{18}: 1\right)$ verzeichneten zu Beginn der Alterung einen Anstieg und erreichten nach einem Jahr eine maximale Konzentration, nahmen danach jedoch wieder ab. Palmitinsäure $\left(\mathrm{C}_{16}: 0\right)$, Linolsäure $\left(\mathrm{C}_{18}: 2\right)$ und Linolensäure $\left(\mathrm{C}_{18}: 3\right)$ nahmen während der Alterung kontinuierlich $\mathrm{ab}$, besonders ausgeprägt war die Reduktion des Linolensäuregehalts. Darüber hinaus nahm das Verhältnis von ungesättigten $\left(\mathrm{C}_{18}: 1, \mathrm{C}_{18}: 2 ; \mathrm{C}_{18}: 3\right)$ zu gesättigten Fettsäuren $\left(\mathrm{C}_{14}: 0 ; \mathrm{C}_{16}: 0 ; \mathrm{C}_{18}: 0\right)$ während der Alterung kontinuierlich ab, und zwar von $1.00 \mathrm{zu}$ Beginn bis 0.43 zum Ende des Alterunsprozesses, als eine Stabilisierung einzutreten schien. Die maximale Geschwindigkeit der Abnahme dieses Verhältnisses war nach 12 bis 18 Monaten Alterung zu beobachten. Die Lipoxygenaseaktivität (LOX) und der Peroxidationswert (POV) stiegen anfangs an und erreichten ihren höchsten Wert nach 6 Monaten der Alterung, nahmen dann jedoch kontinuierlich ab. 
Der Säurewert (AV) und der Gehalt an Malondialdehyd (MDA) zeigten eine Zunahme während der ersten 12 Monate des Alterungsprozesses, nach 12 beziehungsweise 18 Monaten nahmen beide Werte jedoch rasch ab. [Beitr. Tabakforsch. Int. 19 (2001) 315-19]

\section{RESUME}

Des essais ont été menés pour examiner les modifications des concentrations en acides gras supérieurs et les effets sur les caractéristiques biochimiques chez le tabac fluecured au cours du vieillissement. La concentration en lipides totaux chez le tabac flue-cured a diminué progressivement au cours du vieillissement naturel, mais les concentrations des principaux acides gras supérieurs individuels du tabac ont présenté diverses modifications au cours du vieillissement. La concentration en acide myristique $\left(\mathrm{C}_{14}: 0\right)$ a augmenté continuellement tout au long $\mathrm{du}$ vieillissement. Les concentrations en acides stéarique $\left(\mathrm{C}_{18}: 0\right)$ et oléique $\left(\mathrm{C}_{18}: 1\right)$ ont d'abord augmenté et ont atteint leur maximum au bout d'un an, mais ont diminué ensuite. Les concentrations en acides palmitique $\left(\mathrm{C}_{16}: 0\right)$, linoléique $\left(\mathrm{C}_{18}: 2\right)$ et linolénique $\left(\mathrm{C}_{18}: 3\right)$ ont continuellement diminué au cours du vieillissement, phénomène particulièrement marqué pour l'acide linolénique. De plus, le rapport entre acides gras insaturés $\left(\mathrm{C}_{18}: 1, \mathrm{C}_{18}: 2\right.$; $\left.\mathrm{C}_{18}: 3\right)$ et acides gras saturés $\left(\mathrm{C}_{14}: 0 ; \mathrm{C}_{16}: 0 ; \mathrm{C}_{18}: 0\right)$ a diminué constamment au cours du vieillissement, de 1.00 au début jusqu'à 0.43 à la fin du vieillissement, où il paraissait stabilisé. Le taux maximum de diminution du rapport était atteint entre 12 et 18 mois de vieillissement. L'activité de la lipoxygénase (LOX) et la valeur de peroxydation (POV) ont augmenté au début et ont atteint leur niveau maximum au bout de 6 mois, mais ont ensuite constamment diminué. La valeur acide (AV) et la teneur en malondialdéhyde (MDA) ont augmenté au cours des 12 premiers mois de vieillissement et ont diminué rapidement respectivement au cours des 12 et 18 mois de vieillissement. [Beitr. Tabakforsch. Int. 19 (2001) 315-19]

\section{INTRODUCTION}

Flavor is the most important aspect of tobacco quality. It is well known that higher fatty acids play important roles in determining smoke flavor characteristics. Generally, saturated higher fatty acids enhance smoke flavor and result in a smooth taste, while unsaturated higher fatty acids taste pungent. Many studies have been reported on the changes in higher fatty acids of tobacco leaves during growth, ripening and curing $(1,2,3,4,5)$. However, changes in higher fatty acids and related biochemical characteristics of tobacco leaves during aging have seldom been reported (6). In recent years, we have been studying the biological and chemical changes during aging of flue-cured tobacco. In an attempt to understand the improvement of tobacco flavor during aging, the present paper describes the changes in higher fatty acids and related biochemical characteristics of flue-cured tobacco during aging.

\section{EXPERIMENTAL}

\section{Materials}

Flue-cured tobacco leaves (variety NC 89 , grade C3F) were packed tightly and stored in an aging house. The temperature in the house was $15-30^{\circ} \mathrm{C}$ and the humidity was $55-65 \%$ during the aging process. Samples were collected at 6 mo interval during 30 mo of aging, dried, powdered and used for analysis. There were 3 replicate samples analyzed for each sample time. Each replicate sample was from the combined material of 3 separate samplings for that time and replicate.

\section{Methods}

Higher fatty acids were measured by gas chromatography (1). Total lipids were determined by extracting $20 \mathrm{~g}$ leaf material with diethylether in an extraction device for $6 \mathrm{~h}$. The solvent was evaporated and the extract was distilled with water steam for $30 \mathrm{~min}$ to remove the volatile components. The residue was dried and weighted as total lipids.

Lipoxygenase (Linoleate: $\mathrm{O}_{2}$-oxidoreductase E.C. 1.13.11.12, LOX) activity was measured by spectrophotometry under restricted reaction conditions (7).

Peroxidation value (POV) was measured by extracting $3 \mathrm{~g}$ material with $150 \mathrm{~mL}$ diethylether in an extraction device for $6 \mathrm{~h}$. The ether solution was evaporated and the residue dissolved in $150 \mathrm{~mL}$ glacial acetic acid:chloroform $(1: 3, v / v)$ mixture. One $\mathrm{mL}$ saturated potassium iodide solution was added and allowed to react for $5 \mathrm{~min}$. Then the solution was titrated with standard $\mathrm{Na}_{2} \mathrm{~S}_{2} \mathrm{O}_{4}$ solution. POV was calculated according to the titration volume (V) of $\mathrm{Na}_{2} \mathrm{~S}_{2} \mathrm{O}_{4}$ solution based on the dry weight $(W)$ of the ether extract:

$$
\% \mathrm{POV}=\frac{V \cdot N \cdot 0.1269}{W} \cdot 100,
$$

where

$V$ is the titration volume of the $\mathrm{Na}_{2} \mathrm{~S}_{2} \mathrm{O}_{4}$ standard solution, and $N$ is the equivalent concentration of $\mathrm{Na}_{2} \mathrm{~S}_{2} \mathrm{O}_{4}$ standard solution.

Acidic value (AV) was determined by extracting $3 \mathrm{~g}$ material with $150 \mathrm{~mL}$ neutral diethylether in an extraction device for $6 \mathrm{~h}$. The ether solution was mixed with $50 \mathrm{~mL}$ neutral ethanol and the mixture was neutralized with $0.01 \mathrm{~N} \mathrm{KOH}$ standard solution. AV was calculated according to the volume $(V)$ of $\mathrm{KOH}$ solution based on the dry weight $(W)$ of the ether extract:

$$
\% \mathrm{AV}=\frac{V \cdot N \cdot 56.11}{W} \cdot 100,
$$


Table 1.

Lipid content and percent of higher fatty acid contents in flue-cured tobacco during natural aging

\begin{tabular}{l|l|l|l|l|l|l|l|l}
\hline $\begin{array}{l}\text { Aging stage } \\
(\mathrm{mo})\end{array}$ & $\begin{array}{l}\text { Lipid } \\
(\% \mathrm{DW})\end{array}$ & $\begin{array}{l}\text { Myristic } \\
\mathrm{C}_{14}: 0\end{array}$ & $\begin{array}{l}\text { Palmitic } \\
\mathrm{C}_{16}: 0\end{array}$ & $\begin{array}{l}\text { Stearic } \\
\mathrm{C}_{18}: 0\end{array}$ & $\begin{array}{l}\text { Oleic } \\
\mathrm{C}_{18}: 1\end{array}$ & $\begin{array}{l}\text { Linoleic } \\
\mathrm{C}_{18}: 2\end{array}$ & $\begin{array}{l}\text { Linolenic } \\
\mathrm{C}_{18}: 3\end{array}$ & $\begin{array}{l}\text { Unsaturated/saturated } \\
\text { fatty acids }\end{array}$ \\
\hline 0 & 6.51 & 29.55 & 17.08 & 3.41 & 6.53 & 13.55 & 29.9 & 1 \\
6 & 6.17 & 33.25 & 16.29 & 3.52 & 7.66 & 12.6 & 26.71 & 0.86 \\
12 & 5.68 & 38.67 & 15.18 & 3.76 & 9.38 & 10.64 & 22.36 & 0.74 \\
18 & 4.91 & 49.3 & 14.53 & 3.68 & 7.62 & 9.7 & 15.06 & 0.49 \\
24 & 4.69 & 51.63 & 14.34 & 3.66 & 7.1 & 9.62 & 13.64 & 0.44 \\
30 & 4.52 & 52 & 14.32 & 3.66 & 7.02 & 9.59 & 13.35 & 0.43 \\
$\operatorname{LSD}^{\mathrm{b}}(0.05)$ & 0.32 & 2.51 & 0.86 & 0.29 & 0.73 & 0.83 & 2.53 & 0.1 \\
\hline
\end{tabular}

${ }^{\mathrm{a}} \mathrm{DW}=$ dry weight.

${ }^{\mathrm{b}} \mathrm{LSD}=$ least significant difference.

where

$V$ is the titration volume of the $\mathrm{KOH}$ standard solution, and $N$ is the equivalent concentration of $\mathrm{KOH}$ standard solution.

Malondialdehyde (MDA) content was determined by mixing $1 \mathrm{~g}$ material with $20 \mathrm{~mL} \mathrm{10 \%} \mathrm{tricarboxylic} \mathrm{acid} \mathrm{(TCA)}$ solution. The mixture was centrifuged at $1000 \mathrm{~g}$ for 10 min. Of the supernatant $2 \mathrm{~mL}$ was transferred into $2 \mathrm{~mL}$ $0.5 \%$ thiobarbital acid (TBA) solution. The mixture was boiled for $20 \mathrm{~min}$, cooled and centrifuged for $5 \mathrm{~min}$. The optical density (OD) of the solution was measured at 532 and $600 \mathrm{~nm}$. The MDA content was calculated according to the $\mathrm{OD}\left(\mathrm{OD}_{532}-\mathrm{OD}_{600}\right)$ based on leaf dry weight (8):

$$
\operatorname{MDA}(\mu \mathrm{mol} / \mathrm{g} \mathrm{DW})=\frac{\mathrm{OD}_{532}-\mathrm{OD}_{600}}{155} \cdot 20 \cdot 1000 \cdot[3]
$$

Volatile acids (VA) were measured by distilling a mixture of $3 \mathrm{~g}$ material and $50 \mathrm{~mL}$ distilled water plus $1 \mathrm{~mL} 10 \%$ $\mathrm{H}_{3} \mathrm{PO}_{4}$ with steam. An amount of $300 \mathrm{~mL}$ distillate was obtained and neutralized with $0.01 \mathrm{~N} \mathrm{NaOH}$ standard solution. The VA content was calculated according to the volume $(V)$ of $\mathrm{NaOH}$ solution based on leaf dry weight $(W)$ :

$$
\% \mathrm{VA}=\frac{V \cdot N \cdot 0.06}{W} \cdot 100
$$

where

$V$ is the titration volume of the $\mathrm{NaOH}$ standard solution, and $N$ is the equivalent concentration of $\mathrm{NaOH}$ standard solution.

\section{RESULTS AND ANALYSIS}

\section{Changes in higher fatty acids and total lipids}

Significant changes in higher fatty acids in flue-cured leaves were found during aging. Myristic acid $\left(\mathrm{C}_{14}: 0\right)$ increased in absolute amount and relative amount during

the whole aging process (Table 1). Stearic acid $\left(\mathrm{C}_{18}: 0\right)$ and oleic acid $\left(\mathrm{C}_{18}: 1\right)$ increased during the initial stages of aging and reached maximum contents after one year, but decreased thereafter. Palmitic acid $\left(\mathrm{C}_{16}: 0\right)$, linoleic acid $\left(\mathrm{C}_{18}: 2\right)$ and linolenic acid $\left(\mathrm{C}_{18}: 3\right)$ decreased throughout aging. The linolenic acid content decreased drastically during the first $18 \mathrm{mo}$ of aging. Furthermore, the ratio of unsaturated fatty acids $\left(\mathrm{C}_{18}: 1 ; \mathrm{C}_{18}: 2 ; \mathrm{C}_{18}: 3\right)$ and saturated fatty acids $\left(\mathrm{C}_{14}: 0 ; \mathrm{C}_{16}: 0 ; \mathrm{C}_{18}: 0\right)$ decreased continuously during aging, from 1.00 at the initial stage to 0.43 at the end of aging. The maximum rate of decrease of the ratio was between 12 to 18 mo during the aging process.

\section{Changes in lipoxygenase activity}

LOX was found to be present in flue-cured leaves during aging (Figure 1). LOX activity increased initially and reached its highest level after 6 mo of aging, but steadily decreased thereafter.

\section{Changes in peroxidation value and malondialdebyde}

A significant change in POV was found in flue-cured leaves during the aging process. As shown in Figure 2,

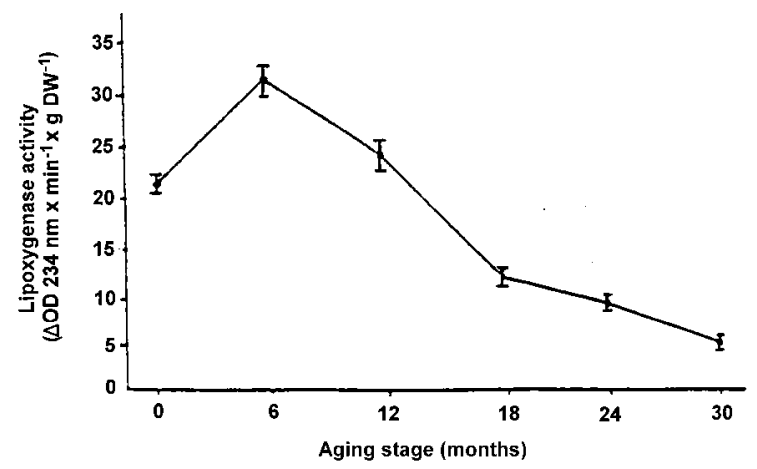

Figure 1.

Changes in lipoxygenase activity of flue-cured tobacco during aging 


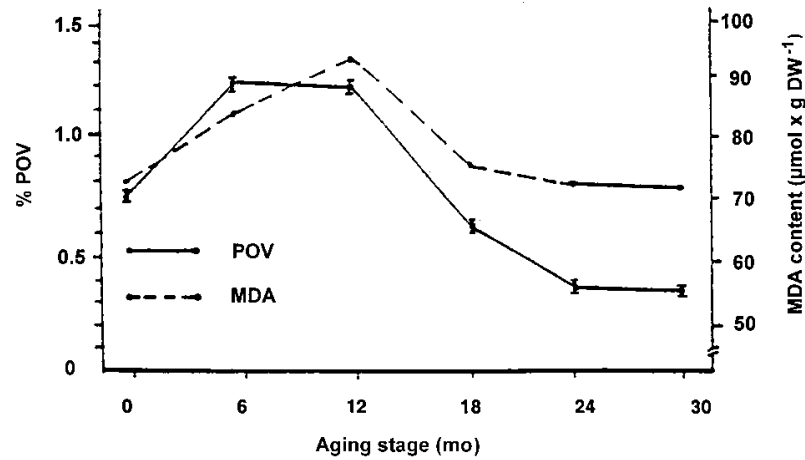

Figure 2.

Changes in peroxidation value and malondialdehyde content of flue-cured tobacco during aging

POV increased for the first two sampling times reaching its highest level at 6 to 12 mo of aging, then decreased. Accordingly, the MDA content increased constantly during the first $12 \mathrm{mo}$ of aging and then decreased at subsequent sample times.

\section{Changes in acid value and volatile acids}

The AV of the leaves increased for the first 18 mo of aging, but decreased rapidly between 12 to 24 mo of aging. VA increased throughout the aging process (Figure 3).

\section{DISCUSSION}

Higher fatty acids, such as myristic acid, in flue-cured tobacco markedly affect tobacco aroma. It is important to study the changes in the higher fatty acids in fluecured tobacco during aging in order to understand the aroma and quality of the tobacco.

LOX catalyzes the oxidation of $\mathrm{C}_{18}$-unsaturated fatty acids with a cis,cis-1,4-pentadiene group to give hydroperoxides, which generally decompose into acids, ketones and aldehydes with short carbon chains. These last-mentioned compounds are responsible for the characteristic odor of the fatty acids containing products that impact aroma. In addition, hydroperoxides and their degradation products can react with proteins, peptides and amino acids to produce volatile compounds. Many studies have been conducted on LOX in other plants and crops $(9,10)$. No information is available on LOX in flue-cured tobacco during aging, therefore, the quantitative changes in higher fatty acids of flue-cured tobacco during aging were studied. It was found that LOX activity was present in flue-cured leaves, but presumably activity was relatively lower at the beginning of aging, because the leaves had been exposed to the higher temperature at the end of the curing stage $\left(70^{\circ} \mathrm{C}\right)$ and redrying stage $\left(80^{\circ} \mathrm{C}\right)$. At the initial stage of aging, the LOX protein may renature and its activity increased gradually under more favorable temperature $\left(25^{\circ} \mathrm{C}\right)$ and relative humidity $(65 \%)$, and reached

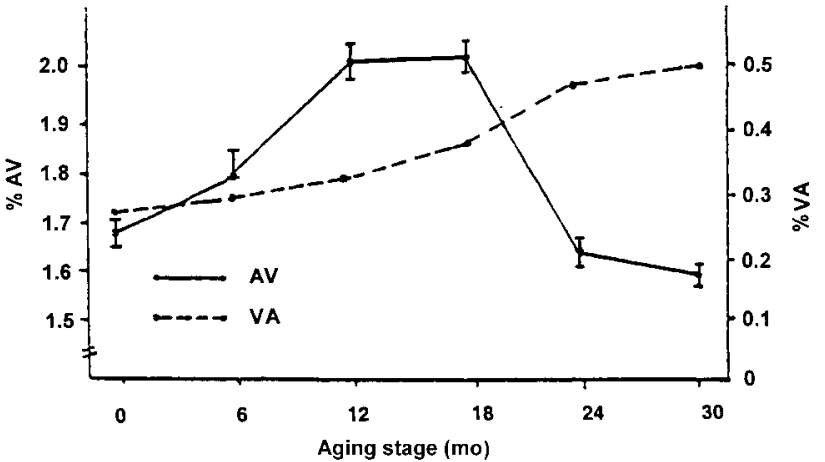

Figure 3.

Changes in acid value and volatile acids content of fluecured tobacco during aging

its highest level at 6 mo of aging, then decreased steadily until termination of the experiment. Accordingly, the unsaturated higher fatty acids decreased rapidly during 6 to 12 mo of aging. It was apparent that the LOX activity was related to the degradation of unsaturated higher fatty acids in flue-cured leaves during aging.

POV, as the main indicator for the peroxidation of lipids, has not been reported before in tobacco research. Unsaturated fatty acids are known to have offensive odor when smoking. POV could indicate their changes during aging. Therefore, POV seems to be one of the important indicators for chemical changes in flue-cured tobacco during aging in our present studies.

MDA is one of the carbonyl products from the degradation of the peroxides of lipids. LOX, POV, and MDA levels were sequential for changes during aging and their highest levels were found after 6 mo, 6 to 12 mo and 12 mo of aging, respectively. This result suggests that the following sequence of reactions occurs during aging of flue-cured tobacco:

\section{Unsaturated higher fatty acids \\ $\Downarrow \quad$ Enzymatic oxidation Autoxidation}

Peroxides

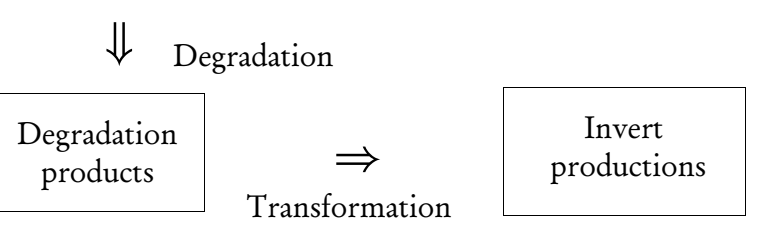

These reactions contribute markedly to the decrease of lipid content and the increase of lower molecular carbonyl compounds, which improve the aroma of the leaves. 
In view of the results and discussion presented here, the most dramatic chemical changes occurred from 6 to 18 mo in the aging processes. Results suggest that the optimum aging time fore flue-cured tobacco should be longer than 18 mo.

\section{REFERENCES}

1. Koiwai, A., F. Suzuki, T. Matsuzaki, and N. Kawashima: The fatty-acid composition of seeds and leaves of Nicotiana spp.; Phytochemistry 22 (1983) 1409-1412.

2. MacCarthy, J.J. and K. Stumpf:The effect of different temperatures on fatty acid synthesis and polyunsaturation in cell suspension cultures; Plantal 47 (1980) 389-395.

3. Pinsky, A., S. Grossman, and M. Trop: Lipoxygenase content and antioxidant activity of some fruit and vegetables; J. Food Sci. 36 (1971) 571-572.

4. Sekiya, J. and T. Hatanaka: Seasonal change in activity of the enzyme system producing cis-3-hexanal and $n$-hexanal from linolenic and linoleic acids in tea leaves; Plant Cell Physiol. 25 (1984) 269-280.

5. Talaqani, T.E., J. Shafik, and F.K. Mustafa: Fatty acids composition of the seed oil of certain tobacco varieties cultivated in northern Iraq; Indian J. Agric. Chem. 19 (1986) 147-154.

6. Swain, A.P. and R.L. Stedman: Analytical studies on the higher fatty acids of tobacco; J. Assoc. Off. Agr. Chem. 45 (1962) 536-540.
7. Berkeley, H.D. and T. Gaillard: Measurement of lipoxygenase activity in crude and partially purified potato extracts; Phytochemistry 15 (1976) 14751479.

8. Shimazaki, K., T. Sakaki, N. Kondo, and K. Sugahara: Active oxygen participation in chlorophyll destruction and lipid peroxidation in $\mathrm{SO}_{2}$-fumigated leaves of spinash; Plant Cell Physiol. 21 (1980) 1193-1204.

9. Gaillard, T. and J.A. Matthew: Lipoxygenase-mediated cleavage of fatty acid to carbonyl fragments in tomato fruits; Phytochemistry 16 (1977) 339-343.

10. Hatanaka, A., T. Kajiwara, J. Sekiya, and Y. Kido: Formation of 12-oxo-trans-10-dodecenoic acid in chloroplasts from thea sinensis leaves; Phytochemistry 16 (1977) 1828-1829.

Address for correspondence

Zhu Dabeng

Zhengzhou Tobacco Research Institute of China National Tobacco Company

88, North Erqi Road

Zhengzhou, Henan 450000,

China 